\title{
The Role of the Thyroid in the Developing Heart
}

\author{
Kazuhiro Maeda, Sachiko Miyagawa-Tomita, and Toshio Nakanishi
}

\section{Keywords}

Thyroid • Thyroid hormone $\bullet$ Thyroid hormone receptor $\bullet$ Heart $\bullet$ Chick embryo

Congenital hypothyroidism $(\mathrm{CH})$ is one of the most common diseases of the endocrine system among newborns. Infants with $\mathrm{CH}$ have been reported to have a high frequency of congenital cardiovascular malformations (CM), such as ventricular and atrial septal defects [1]. Some studies have demonstrated that these cases were due to gene mutations and neural crest abnormality. Infants with $\mathrm{CH}$ and $\mathrm{CM}$ have been shown to have significantly lower $\mathrm{T}_{4}$ levels than those with isolated $\mathrm{CH}$. However, the role of thyroid hormone in the developing heart has not been reported. In this study, we show the thyroid anlage in chick embryos by immunohistochemistry and follow the expression of thyroid hormone receptor during heart development.

1. The thyroid anlage appeared close to the aortic sac at $\mathrm{H} / \mathrm{H} 14$ of chick embryos, as determined by immunohistochemistry (Fig. 16.1a).

2. Avians have access to thyroid hormone long before the embryonic thyroid gland starts to secrete hormones due to the hormone deposition in the yolk and egg white [2].

3. We found that the expression of thyroid hormone receptors during embryonic heart development was earlier than that reported previously published study using RT-PCR (Fig. 16.1b) [3].

K. Maeda • T. Nakanishi

Department of Pediatric Cardiology, Tokyo Women's Medical University, 8-1 Kawada-cho, Shinjuku-ku, Tokyo 162-8666, Japan

S. Miyagawa-Tomita $(\bowtie)$

Department of Pediatric Cardiology, Division of Cardiovascular Development and Differentiation, Medical Research Institute, Tokyo Women's Medical University, Tokyo, Japan e-mail: ptomita@hij.twmu.ac.jp 
A

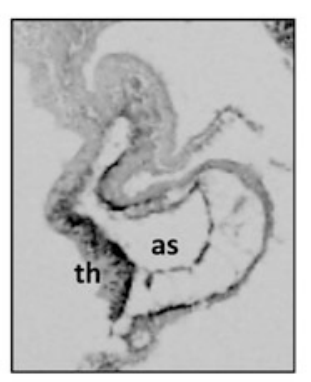

B

$\operatorname{TR} \alpha$

TR $\beta 0$

TRß2

GAPDH
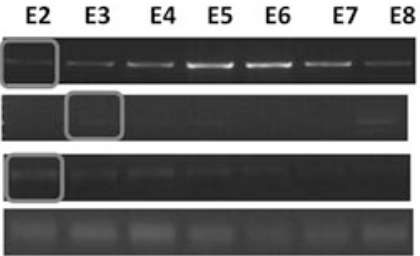

E9 E10 E11 E12 E13 E14 E15

$\operatorname{TR} \beta 0$

TRß2

GAPDH

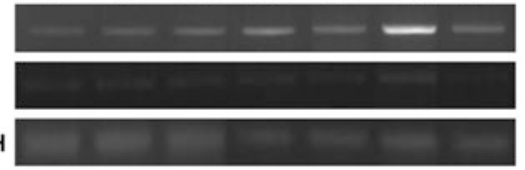

$\begin{array}{lllllll}\text { E16 } & \text { E17 } & \text { E18 } & \text { E19 } & \text { E20 } & \text { Ph2 } & \text { Ph3 }\end{array}$

TRß2

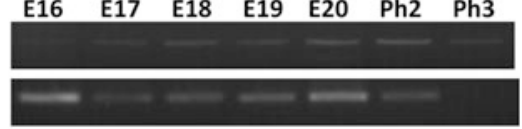

GAPDH

Fig. 16.1 (a) The thyroid anlage appeared close to the aortic sac at $\mathrm{H} / \mathrm{H} 14$. as aortic sac, th thyroid anlage. (b) The expression of thyroid hormone receptors in the developing chick heart. TR $\alpha$ and TR $\beta 2$ were expressed beginning on E2, and TR $\beta 0$ was expressed beginning on E3 (circled). E embryonic day, $P h$ post hatching day

These results suggest that thyroid hormone may contribute to the development of the heart.

Open Access This chapter is distributed under the terms of the Creative Commons AttributionNoncommercial 2.5 License (http://creativecommons.org/licenses/by-nc/2.5/) which permits any noncommercial use, distribution, and reproduction in any medium, provided the original author(s) and source are credited.

The images or other third party material in this chapter are included in the work's Creative Commons license, unless indicated otherwise in the credit line; if such material is not included in the work's Creative Commons license and the respective action is not permitted by statutory regulation, users will need to obtain permission from the license holder to duplicate, adapt or reproduce the material.

\section{References}

1. Olivieri A, Stazi MA, Mastroiacovo P, et al. A population-based study on the frequency of additional congenital malformations in infants with congenital hypothyroidism: data from the Italian Registry for Congenital Hypothyroidism (1991-1998). J Clin Endocrinol Metab. 2002;87:557-62.

2. Prati M, Calvo R, Morreale G, Morreale de Escobar G. L-thyroxine and 3,5,3'-triiodothyronine concentrations in the chicken egg and in the embryo before and after the onset of thyroid function. Endocrinology. 1992;130:2651-9.

3. Forrest D, Sjöberg M, Vennström B. Contrasting developmental and tissue-specific expression of alpha and beta thyroid hormone receptor genes. EMBO J. 1990;9:1519-28. 